\title{
Effect of Water Stress and some Anti - Transpirants on Growth, Yield and Quality of Okra Plants (Abelmoschus esculentus) \\ El-Afifi, S. T. M. ${ }^{1}$; E. A. Ibrahim ${ }^{2}$ and S. A. A. Salem ${ }^{2}$ \\ ${ }^{1}$ Veget. and Flori. Dept., Faculty of Agriculture, Mansoura University, Egypt. \\ ${ }^{2}$ Veget. Res. Dept., Hort. Res. Inst., Agric. Res. Center, Egypt.
}

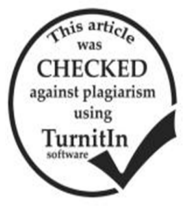

\section{ABSTRACT}

Two field experiments were conducted at private farm in Belqas, Dakahlia Governorate, Egypt during the two summer seasons of 2016 and 2017 to study the effect of irrigation intervals and foliar application of different antitranspirants i.e., silicone in from of potassium silicate $\mathrm{K}_{2} \mathrm{SiO}^{3}(1000 \mathrm{ppm})$, chitosan $(150 \mathrm{ppm})$ and glycine betaine $(700 \mathrm{ppm})$ and their interactions on vegetative growth characters, pod yield, quality traits and chemical constituents of okra (Balady cultivar). The results showed that short irrigation intervals (10days) significantly increased number of leaves/plant, fresh and dry weight (g) as well as leaf area/plant, pod yield/plant, total pod yield (ton/feddan), pod length, chlorophylls $\mathrm{a}, \mathrm{b}$, total chlorophyll and chlorophyll $\mathrm{a} / \mathrm{b}$ ratio of okra leaves and vitamin $\mathrm{C}$, carbohydrate, protein, total sugars contents of okra pods compared with (irrigation at 20 days), except total soluble solids (TSS \%) which had the highest significant values at 20 days irrigation intervals compared with 10 days irrigation intervals. Spraying with all foliar applications led to significant increase all the studied parameters compared with control treatment in both seasons. The superior application was chitosan in particular $150 \mathrm{ppm}$ followed by glycine betaine followed by silicon while control treatment recoded the lowest values in both seasons, respectively, glycine betaine in particular $700 \mathrm{ppm}$ gave the highest values of TSS of okra pods followed by chitosan followed by silicon while control treatment recoded the lowest value. From the obtained results, it could be concluded that Balady cultivar of okra plant which irrigated at 10 days interval and sprayed with chitosan at $150 \mathrm{ppm}$ four times, i.e., 20 days after sowing and repeated each 10 days interval, respectively recorded the highest values of all studied traits of okra plant compared to other treatments, except Total soluble solids (TSS \%) which had the highest significant values of okra pods with the interaction between (irrigation every 20 days interval $\times$ foliar sprayed by $700 \mathrm{ppm}$ of glycine betaine) during both seasons.

Keywords: okra (Abelmoschus esculentus L.), irrigation intervals, antitranspirants, silicon, chitosan, glycine betaine, growth, pod yield, quality.

\section{INTRODUCTION}

Okra (Abelmoschus esculentus) is an important summer vegetable crop in Egypt, which is consumed locally or exported abroad. The green pods of okra used fresh, frozen or as pickles.

Despite considerable resistance of okra to drought it requires large amounts of water during the growing, lack of water has deleterious effects on the yield. The maximum loss of yield happened when continuous water shortages continuously until the first harvest (Abd El-Kader et al., 2010).

One of the most important strategies for increasing the productivity of okra under normal irrigation and drought stress using compounds of antitranspirants. These compounds should be harmless to humans and inexpensive.

Silicon is one of the most important antiperspirants used, and after oxygen the second most abundant element in the soil solution and in the earth's crust. Foliar spray of silicon reduces the negative effects of drought (Bukhari et al., 2015).

Chitosan stimulate plant growth (Mondal et al., 2012). Chitosan act as antitranspirant compound which effecte on many crops (Khan et al., 2002).

Glycine betaine is amino acid which considers a vital tonic that is rapidly absorbed and transported within the plant parts. Exogenously applied glycine betaine can be used to increase the extent of plant height, chlorophyll (a and $\mathrm{b}$ ), yield and yield components in drought stress condition and without drought stress (Miri and Armin, 2013).

This study designed to know the effect of water stress and spray some anti- transpirants such as silicon, chitosan, glycine betaine and their interactions on growth, yield and quality of okra plants (Abelmoschus esculentus L. Moench) which had grown under normal irrigation or drought stress conditions, without adversely affecting growth, quality and yield of okra.

\section{MATERIALS AND METHODS}

\section{1- The experimental design and treatments}

Split-plot design was the experimental layout with three replicates. These experiments included eight treatments which were the combination between 2 irrigation intervals and 4 foliar applications of antitranspirants. Two irrigation regimes (every 10 and 20 days intervals starting after 1st irrigation) were assigned in the main plots. The irrigation numbers were totally 18 and 9 times, respectively, while the foliar applications were randomly distributed in the sub-plots. The plot area was 12 $\mathrm{m} 2$ (4-ridges, each $5 \mathrm{~m}$ length, and $0.6 \mathrm{~m}$ width). Seeds were sown with $30 \mathrm{~cm}$ spacing between plants on one side of ridges at a rate of 3-5 seeds at hills by hand at the depth of 1-2 cm of soil and then covered with wet and dry soil. The seeds were sown on $20^{\text {th }}$ March of 2016 and 2017. After germination plants were thinned on two plants/ hill.

Table 1. Mechanical and chemical analysis of the soil experimental.

\begin{tabular}{|c|c|c|c|c|c|}
\hline Properties & 10 & & Properties & Soluble & /100g soil) \\
\hline & Value & & & Valus & \\
\hline & 2016 & 2017 & & 2016 & 2017 \\
\hline Soil texture & Clay-loam & Clay-loam & $\mathrm{HCO}^{-}$ & 0.62 & 0.63 \\
\hline Sand $(\%)$ & 16.22 & 15.74 & $\mathrm{SO}^{--}$ & 0.05 & 0.07 \\
\hline Silt (\%) & 22.06 & 22.86 & & ations (m & \\
\hline Clay $(\%)$ & 61.72 & 61.40 & & Value & \\
\hline Organic matter $\%$ & 1.34 & 1.50 & Properties & 2016 & 2017 \\
\hline & Chemical & & $\mathrm{Ca}^{\mathrm{T}}$ & 0.61 & 0.62 \\
\hline & Value & & $\mathrm{Mg}^{\top}$ & 0.31 & 0.33 \\
\hline & 2016 & 2017 & $\mathrm{Na}^{\top}$ & 0.22 & 0.21 \\
\hline pH value & 7.80 & 8.20 & & ro-elemer & \\
\hline $\mathrm{E} C(\mathrm{mmohs} / \mathrm{cm})$ & 0.69 & 0.57 & & Value & \\
\hline & & & & 2016 & 2017 \\
\hline & & & $\mathrm{N}$ & 45.50 & 45.70 \\
\hline & & & $\mathrm{P}$ & 11 & 11.30 \\
\hline & & & $\mathrm{K}$ & 209 & 213 \\
\hline
\end{tabular}


The treatments were arranged as follow

a. Irrigation intervals (main plot)

Normal irrigation at (10 days intervals), Drought stress at (20 days intervals).

b. Foliar applications of antitranspirants (sub plot)

Control (sprayed with tap water), Silicon in form of potassium silicate (K2SiO3) at $1000 \mathrm{ppm}$, Chitosan at $150 \mathrm{ppm}$ and Glycine betaine at $700 \mathrm{ppm}$.

The plants were sprayed with foliar treatments four times, 20 days after sowing and repeated each 10 days interval. The normal agricultural practices of okra production were followed according to the recommendations of Egyptian Ministry of Agriculture. Pods harvesting was done according to the standard characteristics for exportation.

\section{2- Data recorded were as follows}

Vegetative growth characters

Five plants were marked randomly after 50 days of sowing from each plot for determining the following data: number of leaves/ plant, fresh weights/ plant (g), dry weights/ plant (g) and leaf area/ plant $(\mathrm{cm} 2)$, it was estimated by drying each plant at $70^{\circ} \mathrm{c}$ to a constant weight, leaf area was recorded according to (Koller, 1972).

\section{Pod yield and its components}

In each harvest green pods were harvested of each plot at the proper maturing stage, counted and weighted and the following parameters were collected: average of pod length $(\mathrm{cm})$, pod yield/plant $(\mathrm{g})$ and total pod yield (ton/feddan) of okra pods.

Chemical composition of leaves: It was determined in leaves before the beginning of flowering and the following parameters were collected: chlorophylls a, b, total chlorophyll and chlorophyll $\mathrm{a} / \mathrm{b}$ ratio of leaves were determined according to Lichtenthaler and Wellburn (1983).

Chemical composition of pods: Representative samples of 10 okra pods were randomly taken from each treatment to determine the quality parameters of okra pods vitamin $\mathrm{C}$ (mg/100gf.w.) was determined in in juice from fresh pods by titration with 2.6 diclorophenol indophenol blue dye according to the method reported in (AOAC, 1975), total carbohydrates was determined according to the method described by (Sadasivam and Manickam, 1996), protein was determined according to (AOAC, 2000), crude protein of each sample was calculated by multiplying the total nitrogen by the factor 6.25 , Total sugars was determined according to the method described by Sadasivam and Manickam (1996) and total soluble solids (TSS) was estimated using Galli 110 refractometer according to (AOAC, 2000).

\section{Statistical analysis}

All statistical analyses were performed using analysis of variance technique by means of Costat

Table 2 . Effect of irrigation intervals and foliar application of antitranspirants on number of leaves /plant, fresh and dry weight (g) as well as leaf area/plant $\left(\mathrm{cm}^{2}\right)$ of okra in the two seasons of 2016 and 2017.

\begin{tabular}{lccccccccc}
\hline \multirow{2}{*}{ Treatments } & & \multicolumn{2}{c}{$\begin{array}{c}\text { Number of } \\
\text { leaves/plant }\end{array}$} & $\begin{array}{c}\text { Fresh weight/plant } \\
(\mathbf{g})\end{array}$ & $\begin{array}{c}\text { Dry weight/plant } \\
(\mathbf{g})\end{array}$ & \multicolumn{2}{c}{$\begin{array}{c}\text { Leaf area/plant } \\
\left(\mathbf{c m}^{2}\right)\end{array}$} \\
\hline & & $\mathbf{2 0 1 6}$ & $\mathbf{2 0 1 7}$ & $\mathbf{2 0 1 6}$ & $\mathbf{2 0 1 7}$ & $\mathbf{2 0 1 6}$ & $\mathbf{2 0 1 7}$ & $\mathbf{2 0 1 6}$ & $\mathbf{2 0 1 7}$ \\
\hline Irrigation & Normal Irrigation at 10 days & $27.55 \mathrm{a}$ & $29.33 \mathrm{a}$ & $493.84 \mathrm{a}$ & $499.09 \mathrm{a}$ & $63.08 \mathrm{a}$ & $65.68 \mathrm{a}$ & $4417.20 \mathrm{a}$ & $4600.27 \mathrm{a}$ \\
intervals & Drought Stresss at 20 days & $20.17 \mathrm{~b}$ & $20.79 \mathrm{~b}$ & $383.85 \mathrm{~b}$ & $387.97 \mathrm{~b}$ & $52.17 \mathrm{~b}$ & $53.54 \mathrm{~b}$ & $3405.17 \mathrm{~b}$ & $3586.66 \mathrm{~b}$ \\
\hline \multirow{3}{*}{ Foliar } & Control Tap water & $19.66 \mathrm{c}$ & $21 \mathrm{c}$ & $384.48 \mathrm{~d}$ & $390.66 \mathrm{~d}$ & $51.90 \mathrm{~d}$ & $54.08 \mathrm{~d}$ & $3453.61 \mathrm{~d}$ & $3682.74 \mathrm{~d}$ \\
application & Silicon 1000 ppm & $24.16 \mathrm{~b}$ & $25.41 \mathrm{~b}$ & $443.95 \mathrm{c}$ & $447.55 \mathrm{c}$ & $57.53 \mathrm{c}$ & $59.73 \mathrm{c}$ & $3790.92 \mathrm{c}$ & $3952.97 \mathrm{c}$ \\
& Chitosan 150 ppm & $26.30 \mathrm{a}$ & $27.50 \mathrm{a}$ & $470.85 \mathrm{a}$ & $475.78 \mathrm{a}$ & $61.81 \mathrm{a}$ & $63.46 \mathrm{a}$ & $4485.52 \mathrm{a}$ & $4581.66 \mathrm{a}$ \\
& Glycine betaine 700 ppm & $25.31 \mathrm{ab}$ & $26.33 \mathrm{~b}$ & $456.11 \mathrm{~b}$ & $460.13 \mathrm{~b}$ & $59.26 \mathrm{~b}$ & $61.16 \mathrm{~b}$ & $3914.71 \mathrm{~b}$ & $4156.50 \mathrm{~b}$ \\
\hline
\end{tabular}

computer software. Using the differences between individual pairs of treatment means were compared using Duncan Multiple Range Test at 5\% according to Snedecor and Cochran (1989).

\section{RESULTS AND DISCUSSION}

\section{Vegetative growth parameters}

\section{Effect of irrigation intervals}

Table 2 show that the highest significant values of number of leaves/plant, fresh and dry weight/plant and leaf area/plant were recorded at 10 days from irrigation intervals during both seasons compared with irrigation intervals at 20 days. The differences between irrigation intervals could be suggested increasing water quantity applied to plant caused keeping higher moisture content in the soil and this in turn might the plant metabolism and thus leads to increase plant growth characters and produce higher dry matter. This result is in agreement with those of Saied (2000) on sugar beet. Such results are in agreement with Altaf et al. (2015) on okra.

\section{Effect of foliar application of antitranspirants}

Table 2 show that the highest significant values of number of leaves/plant, fresh and dry weight/plant and leaf area/plant were recorded with spraying plants by chitosan compared with glycine betaine, silicon meanwhile the control had the lowest values of mentioned growth parameters in both seasons. These results are in harmonious with Abbas et al. (2017) as for silicon, ElSherbini (2015) as for chitosan, Ragab et al. (2015) as for glycine betaine. growth might be due to that silicon improves protection against pathogens and enhances the growth. (Greger et al., 2011).

Foliar application of chitosan increases photosynthesis, promotes and enhances plant growth, stimulates nutrient uptake and increases germination (Kim et al., 2005). plant tolerance to some abiotic stresses such as salt, drought, and extreme temperatures. (Quan et al., 2004).

\section{Effect of the interactions:}

Table 3 show that the highest significant values of number of leaves/plant, fresh and dry weight/plant and leaf area/plant of okra plant were obtained with irrigation every 10 days $\times$ foliar sprayed by $150 \mathrm{ppm}$ of chitosan) followed by (irrigation every 10 days $\times$ foliar sprayed by $700 \mathrm{ppm}$ of glycine betaine) and the lowest one was the interaction (irrigation every 20 days $\times$ control) in both seasons.

Similar results were harmonious with Farouk and Abd EL Mohsen (2011), Rakha (2014) and Raza et al. (2014).
The stimulative effect of silicon on vegetative

Glycine betaine play important role in increase 
Table 3. Effect of the interaction between irrigation intervals and foliar applications of antitranspirants on number of leaves/plant, fresh and dry weight as well as leaf area/plant of okra in the two seasons of 2016 and 2017.

\begin{tabular}{lccccccccc}
\hline \multirow{2}{*}{ Treatments } & & \multicolumn{2}{c}{$\begin{array}{c}\text { Number of } \\
\text { leaves/plant }\end{array}$} & $\begin{array}{c}\text { Fresh weight/plant } \\
(\mathbf{g})\end{array}$ & $\begin{array}{c}\text { Dry weight/plant } \\
(\mathbf{g})\end{array}$ & \multicolumn{2}{c}{$\begin{array}{c}\text { Leaf area/plant } \\
\left(\mathbf{c m}^{2}\right)\end{array}$} \\
\hline & & $\mathbf{2 0 1 6}$ & $\mathbf{2 0 1 7}$ & $\mathbf{2 0 1 6}$ & $\mathbf{2 0 1 7}$ & $\mathbf{2 0 1 6}$ & $\mathbf{2 0 1 7}$ & $\mathbf{2 0 1 6}$ & $\mathbf{2 0 1 7}$ \\
\hline \multirow{2}{*}{ Normal } & Control Tap water & $22.33 \mathrm{c}$ & $24 \mathrm{~d}$ & $438.53 \mathrm{~d}$ & $442.66 \mathrm{~d}$ & $57.42 \mathrm{~d}$ & $59.43 \mathrm{~d}$ & $3682.73 \mathrm{~d}$ & $4084.82 \mathrm{c}$ \\
Irrigation & Silicon 1000 ppm & $28 \mathrm{~b}$ & $29.33 \mathrm{c}$ & $493.06 \mathrm{c}$ & $497.76 \mathrm{c}$ & $62.06 \mathrm{c}$ & $64.93 \mathrm{c}$ & $4143.67 \mathrm{c}$ & $4224.28 \mathrm{c}$ \\
at 10 days & Chitosan 150 ppm & $30.66 \mathrm{a}$ & $33 \mathrm{a}$ & $531.16 \mathrm{a}$ & $538.73 \mathrm{a}$ & $68.33 \mathrm{a}$ & $70.73 \mathrm{a}$ & $5451.33 \mathrm{a}$ & $5470.66 \mathrm{a}$ \\
& Glycine betaine 700 ppm & $29.20 \mathrm{ab}$ & $31 \mathrm{~b}$ & $512.60 \mathrm{~b}$ & $517.20 \mathrm{~b}$ & $64.53 \mathrm{~b}$ & $67.63 \mathrm{~b}$ & $4391.09 \mathrm{~b}$ & $4621.33 \mathrm{~b}$ \\
\hline \multirow{2}{*}{ Drought } & Control Tap water & $17 \mathrm{~d}$ & $18 \mathrm{f}$ & $330.43 \mathrm{~h}$ & $338.66 \mathrm{~h}$ & $46.38 \mathrm{f}$ & $48.73 \mathrm{~g}$ & $3224.50 \mathrm{~g}$ & $3280.66 \mathrm{e}$ \\
Stresss & Silicon 1000 ppm & $20.33 \mathrm{c}$ & $21.50 \mathrm{e}$ & $394.83 \mathrm{~g}$ & $397.33 \mathrm{~g}$ & $53 \mathrm{e}$ & $54.53 \mathrm{f}$ & $3438.16 \mathrm{f}$ & $3681.66 \mathrm{~d}$ \\
at 20 days & Chitosan 150 ppm & $21.93 \mathrm{c}$ & $22 \mathrm{e}$ & $410.53 \mathrm{e}$ & $412.83 \mathrm{e}$ & $55.30 \mathrm{de}$ & $56.20 \mathrm{e}$ & $3519.71 \mathrm{e}$ & $3692.66 \mathrm{~d}$ \\
& Glycine betaine 700 ppm & $21.43 \mathrm{c}$ & $21.66 \mathrm{e}$ & $399.63 \mathrm{f}$ & $403.06 \mathrm{f}$ & $54 \mathrm{e}$ & $54.70 \mathrm{f}$ & $3438.33 \mathrm{f}$ & $3691.66 \mathrm{~d}$ \\
\hline
\end{tabular}

\section{Pod yield and its components Effect of irrigation intervals}

Data in Table 4 show that irrigation intervals at 10 days had the highest values of pod length $\mathrm{cm}$, the highest significant values of pod yield/plant and total pod yield ton/feddan in both seasons respectively compared with irrigation intervals at20 days.

Irrigation intervals at 20 days caused water stress to okra plant which considered as one of the most important limitations to photosynthesis and plant productivity (Tezara et al., 2005). Similar results were obtained by Hussein et al. (2011) on okra.

\section{Effect of foliar application of antitranspirants}

It is obvious from the data in Table 4 that all foliar applications cause increase in all studied parameters compared with control. The highest values of pod length $\mathrm{cm}$, the highest significant values of pod yield/plant and total pod yield ton/feddan were obtained when okra plants sprayed with chitosan followed by glycine betaine followed by silicon and the lowest application in all studied parameters was control.

There was insignificant difference between the effect of foliar application of chitosan and glycine betaine and there was insignificant difference between application of glycine betaine and silicon on pod length, pod yield/plant and total pod yield/feddan in both seasons. The foliar application chitosan, glycine betaine and silicon had a similar effect on pod length in second season. These results are in accordance with El-Sherbini (2015) as for silicon, El-Badawy (2014) as for chitosan, Ragab et al. (2015) as for glycine betaine.

Concerning silicon, the increase in yield from silicon treated plants is a result of deposition of the element under the leaf epidermis which caused a production of phenols, physical mechanism of defense, which reduces lodging, stimulates phytoalexin production, decreases transpiration losses and increases photosynthesis capacity of crop plants (Korndorfer et al., 2004 and Ahmad et al., 2012).

Foliar application of chitosan lead to stimulate leaves, shoots, roots, photosynthetic rate and chlorophyll content in plant (Khan et al., 2002 and Gornik et al., 2008) which caused in increment in the vigor growth followed by active translocation of photoassimilates from source to sink tissues followed by increase yield.

Concerning glycine betaine, the improveme in yield and yield components due to play an important role in increasing plant tolerance to abiotic stresses such as drought, extreme temperatures and salt (Quan et al., 2004).

\section{Effect of the interactions}

Table 5 show that the highest significant values of all pod characters of okra plant were obtained with the interaction between (irrigation every 10 days $\times$ foliar sprayed with $150 \mathrm{ppm}$ of chitosan) followed by (irrigation every 10 days $\times$ foliar sprayed with $700 \mathrm{ppm}$ of glycine betaine) and the lowest one was the interaction between (drought stress irrigation every 20 days $\times$ control) in first and second season.

There was insignificant difference between interaction between (irrigation every 10 days $\times$ foliar sprayed with $150 \mathrm{ppm}$ of chitosan) and (irrigation every 10 days $\times$ foliar sprayed with $700 \mathrm{ppm}$ of glycine betaine) and There was insignificant difference between interaction between (irrigation every 10 days $\times$ foliar sprayed with 700 ppm of glycine betaine) and (irrigation every 10 days $\times$ foliar sprayed with $1000 \mathrm{ppm}$ of silicon) on pod yield/plant and total pod yield/feddan in both seasons.

Similar results were obtained by Farouk and Abd EL Mohsen (2011), Rakha (2014) and Noreen et al. (2015).

Table 4.Effect of irrigation intervals and foliar application of antitranspirants on pod length, pod yield/plant and total pod yield ton/feddan of okra in the two seasons of 2016 and 2017.

\begin{tabular}{|c|c|c|c|c|c|c|c|}
\hline \multirow[t]{2}{*}{ Treatments } & & \multicolumn{2}{|c|}{$\begin{array}{c}\text { The pod length } \\
(\mathrm{cm})\end{array}$} & \multicolumn{2}{|c|}{$\begin{array}{c}\text { Pod yield/plant } \\
\text { (g) }\end{array}$} & \multicolumn{2}{|c|}{$\begin{array}{c}\text { Total pod yield } \\
\text { (ton/feddan) }\end{array}$} \\
\hline & & 2016 & 2017 & 2016 & 2017 & 2016 & 2017 \\
\hline \multirow{2}{*}{$\begin{array}{l}\text { Irrigation } \\
\text { intervals } \\
\end{array}$} & Normal Irrigation at 10 days & $3.12 \mathrm{a}$ & $3.21 \mathrm{a}$ & $362.13 \mathrm{a}$ & $365.28 \mathrm{a}$ & $8.04 \mathrm{a}$ & $8.11 \mathrm{a}$ \\
\hline & Drought Stresss at 20 days & $2.42 \mathrm{~b}$ & $2.50 \mathrm{~b}$ & $216.37 \mathrm{~b}$ & $218.85 \mathrm{~b}$ & $4.80 \mathrm{~b}$ & $4.86 b$ \\
\hline \multirow{4}{*}{$\begin{array}{l}\text { Foliar } \\
\text { application }\end{array}$} & Control Tap water & $2.61 \mathrm{c}$ & $2.71 \mathrm{~b}$ & $256.87 \mathrm{c}$ & $260.32 \mathrm{c}$ & $5.69 \mathrm{c}$ & $5.78 \mathrm{c}$ \\
\hline & Silicon $1000 \mathrm{ppm}$ & $2.77 \mathrm{~b}$ & $2.87 \mathrm{a}$ & $295.2 \mathrm{~b}$ & $297.52 \mathrm{~b}$ & $6.56 \mathrm{~b}$ & $6.61 \mathrm{~b}$ \\
\hline & Chitosan 150 ppm & $2.88 \mathrm{a}$ & $2.93 a$ & $305.55 a$ & $308.02 \mathrm{a}$ & $6.79 \mathrm{a}$ & $6.84 a$ \\
\hline & Glycine betaine $700 \mathrm{ppm}$ & $2.81 \mathrm{ab}$ & $2.91 \mathrm{a}$ & $299.4 \mathrm{ab}$ & $302.4 \mathrm{ab}$ & $6.65 \mathrm{ab}$ & $6.72 \mathrm{ab}$ \\
\hline
\end{tabular}


Table 5. Effect of the interaction between irrigation intervals and foliar applications of antitranspirants on pod yield/plant, total pod yield/feddan and pod length of okra plant in the two seasons of 2016 and 2017.

\begin{tabular}{|c|c|c|c|c|c|c|c|}
\hline \multirow[t]{2}{*}{ Treatments } & & \multicolumn{2}{|c|}{$\begin{array}{c}\text { The pod length } \\
\text { (cm) }\end{array}$} & \multicolumn{2}{|c|}{$\begin{array}{c}\text { Pod yield/plant } \\
\text { (g) }\end{array}$} & \multicolumn{2}{|c|}{$\begin{array}{c}\text { Total pod yield } \\
\text { (ton/feddan) }\end{array}$} \\
\hline & & 2016 & 2017 & 2016 & 2017 & 2016 & 2017 \\
\hline \multirow{4}{*}{$\begin{array}{l}\text { Normal Irrigation } \\
\text { at } 10 \text { days }\end{array}$} & Control Tap water & $2.93 \mathrm{c}$ & $3.03 \mathrm{c}$ & $321 \mathrm{c}$ & $324.45 \mathrm{c}$ & $7.11 \mathrm{c}$ & $7.21 \mathrm{c}$ \\
\hline & Silicon $1000 \mathrm{ppm}$ & $3.1 \mathrm{~b}$ & $3.2 \mathrm{~b}$ & $369.3 \mathrm{~b}$ & $372 \mathrm{~b}$ & $8.20 \mathrm{~b}$ & $8.26 b$ \\
\hline & Chitosan 150 ppm & $3.26 \mathrm{a}$ & $3.30 \mathrm{a}$ & $383.1 \mathrm{a}$ & $385.95 \mathrm{a}$ & $8.51 \mathrm{a}$ & $8.57 \mathrm{a}$ \\
\hline & Glycine betaine $700 \mathrm{ppm}$ & $3.20 \mathrm{a}$ & $3.30 \mathrm{a}$ & $375.15 \mathrm{ab}$ & $378.75 \mathrm{ab}$ & $8.33 \mathrm{ab}$ & $8.41 \mathrm{ab}$ \\
\hline \multirow{4}{*}{$\begin{array}{l}\text { Drought Stresss } \\
\text { at } 20 \text { days }\end{array}$} & Control Tap water & $2.30 \mathrm{e}$ & $2.39 \mathrm{e}$ & $192.75 \mathrm{e}$ & $196.2 \mathrm{e}$ & $4.28 \mathrm{e}$ & $4.36 \mathrm{e}$ \\
\hline & Silicon $1000 \mathrm{ppm}$ & $2.44 \mathrm{~d}$ & $2.54 \mathrm{~d}$ & $221.1 \mathrm{~d}$ & $223.05 \mathrm{~d}$ & $4.91 \mathrm{~d}$ & $4.95 \mathrm{~d}$ \\
\hline & Chitosan 150 ppm & $2.50 \mathrm{~d}$ & $2.56 \mathrm{~d}$ & $228 \mathrm{~d}$ & $230.1 \mathrm{~d}$ & $5.06 \mathrm{~d}$ & $5.11 \mathrm{~d}$ \\
\hline & Glycine betaine $700 \mathrm{ppm}$ & $2.43 \mathrm{~d}$ & $2.53 \mathrm{~d}$ & $223.65 d$ & $226.05 \mathrm{~d}$ & $4.97 \mathrm{~d}$ & $5.02 \mathrm{~d}$ \\
\hline
\end{tabular}

\section{Chemical composition of plants}

Chemical composition of leaves

\section{Effect of irrigation intervals}

Data in Table 6 show that the highest significant values of chlorophylls a, b, total chlorophyll and chlorophyll $a / b$ ratio of okra leaves were recorded at 10 days intervals during both seasons compared with irrigation intervals at 20 days which had the lowest significant values of the studied parameters. Similar results were obtained by Maghsoudi et al. (2015).

Chemical composition of okra leaves was lower at the longer regime at 20 days intervals compared with irrigation intervals at 10 days because the nutrient mobility in the soil is towered and the nutrients flow to root absorption zone rate decreased when soil moisture decreased, the results obtained by (Mahmoud and Hafiz, 2002).

Effect of foliar application of antitranspirants

Table 6 show that the highest values of chlorophylls $\mathrm{a}, \mathrm{b}$, total chlorophyll and chlorophyll $\mathrm{a} / \mathrm{b}$ ratio of okra leaves were obtained when okra plants sprayed with chitosan followed by glycine betaine and silicon which had a similar effect meanwhile the lowest application in all studied parameters was control.

The results are agreed with Maghsoudi et al. (2016) as for silicon, Abu-Muriefah (2013) as for chitosan, Miri and Armin (2013) as for glycine betaine.

Table 6. Effect of irrigation intervals and foliar applications of antitranspirants on chlorophylls a, b, total chlorophyll and chlorophyll a/b ratio of okra leaves in the two seasons of 2016 and 2017.

\begin{tabular}{|c|c|c|c|c|c|c|c|c|c|}
\hline \multirow[t]{2}{*}{ Treatments } & & \multicolumn{2}{|c|}{$\begin{array}{c}\text { Chlorophyll a } \\
\text { (mg/gf w) }\end{array}$} & \multicolumn{2}{|c|}{$\begin{array}{c}\text { Chlorophyll b } \\
\text { (mg/gf w) }\end{array}$} & \multicolumn{2}{|c|}{$\begin{array}{l}\text { Total. Chlorophyll } \\
\text { (mg/gf w) }\end{array}$} & \multicolumn{2}{|c|}{$\begin{array}{l}\text { Chlorophyll } \\
\text { a/b ratio }\end{array}$} \\
\hline & & 2016 & 2017 & 2016 & 2017 & 2016 & 2017 & 2016 & 2017 \\
\hline \multirow{2}{*}{$\begin{array}{l}\text { Irrigation } \\
\text { intervals }\end{array}$} & Normal Irrigation at 10 days & $0.62 \mathrm{a}$ & $0.67 \mathrm{a}$ & $0.42 \mathrm{a}$ & $0.45 \mathrm{a}$ & $1.04 \mathrm{a}$ & $1.13 \mathrm{a}$ & $1.48 \mathrm{a}$ & $1.46 \mathrm{a}$ \\
\hline & Drought Stresss at 20 days & $0.55 b$ & $0.62 \mathrm{~b}$ & $0.39 \mathrm{~b}$ & $0.44 \mathrm{~b}$ & $0.95 \mathrm{~b}$ & $1.06 \mathrm{~b}$ & $1.39 \mathrm{~b}$ & $1.39 \mathrm{~b}$ \\
\hline \multirow{4}{*}{$\begin{array}{l}\text { Foliar } \\
\text { application }\end{array}$} & Control Tap water & $0.55 \mathrm{c}$ & $0.62 \mathrm{c}$ & $0.39 \mathrm{c}$ & $0.44 \mathrm{c}$ & $0.95 \mathrm{c}$ & $1.07 \mathrm{c}$ & $1.39 \mathrm{c}$ & $1.40 \mathrm{c}$ \\
\hline & Silicon $1000 \mathrm{ppm}$ & $0.58 \mathrm{~b}$ & $0.64 \mathrm{~b}$ & $0.40 \mathrm{~b}$ & $0.45 \mathrm{~b}$ & $0.99 b$ & $1.09 \mathrm{~b}$ & $1.42 \mathrm{bc}$ & $1.42 \mathrm{~b}$ \\
\hline & Chitosan 150 ppm & $0.62 \mathrm{a}$ & $0.66 \mathrm{a}$ & $0.41 \mathrm{a}$ & $0.45 \mathrm{a}$ & $1.04 \mathrm{a}$ & $1.12 \mathrm{a}$ & $1.48 \mathrm{a}$ & $1.46 \mathrm{a}$ \\
\hline & Glycine betaine $700 \mathrm{ppm}$ & $0.59 \mathrm{~b}$ & $0.64 \mathrm{~b}$ & $0.41 b$ & $0.45 b$ & $1.00 \mathrm{~b}$ & $1.10 \mathrm{~b}$ & $1.44 b$ & $1.43 b$ \\
\hline
\end{tabular}

Table 7. Effect of the interaction between irrigation intervals and foliar applications of antitranspirants on Chlorophylls a, b, Total chlorophyll and Chlorophyll a/b ratio of okra leaves in the two seasons of 2016 and 2017.

\begin{tabular}{|c|c|c|c|c|c|c|c|c|c|}
\hline \multicolumn{2}{|c|}{ Treatments } & \multicolumn{2}{|c|}{$\begin{array}{c}\text { Chlorophyll a } \\
\text { (mg/gf w) }\end{array}$} & \multicolumn{2}{|c|}{$\begin{array}{c}\text { Chlorophyll b } \\
\text { (mg/gf w) }\end{array}$} & \multicolumn{2}{|c|}{$\begin{array}{l}\text { Total. Chlorophyll } \\
\text { (mg/ gf w) }\end{array}$} & \multicolumn{2}{|c|}{$\begin{array}{l}\text { Chlorophyll } \\
\text { a/b ratio }\end{array}$} \\
\hline & & 2016 & 2017 & 2016 & 2017 & 2016 & 2017 & 2016 & 2017 \\
\hline \multirow{4}{*}{$\begin{array}{l}\text { Normal } \\
\text { Irrigation } \\
\text { at } 10 \text { days }\end{array}$} & Control Tap water & $0.57 \mathrm{e}$ & $0.64 \mathrm{c}$ & $0.40 \mathrm{~cd}$ & $0.45 \mathrm{bc}$ & $0.97 \mathrm{~d}$ & $1.09 \mathrm{c}$ & $1.42 \mathrm{cde}$ & $1.42 \mathrm{c}$ \\
\hline & Silicon $1000 \mathrm{ppm}$ & $0.61 \mathrm{c}$ & $0.67 \mathrm{~b}$ & $0.42 \mathrm{~b}$ & $0.45 \mathrm{~b}$ & $1.03 \mathrm{~b}$ & $1.12 \mathrm{~b}$ & $1.47 \mathrm{bc}$ & $1.46 \mathrm{~b}$ \\
\hline & Chitosan 150 ppm & $0.68 \mathrm{a}$ & $0.70 \mathrm{a}$ & $0.43 \mathrm{a}$ & $0.46 \mathrm{a}$ & $1.11 \mathrm{a}$ & $1.17 \mathrm{a}$ & $1.56 \mathrm{a}$ & $1.51 \mathrm{a}$ \\
\hline & Glycine betaine $700 \mathrm{ppm}$ & $0.63 \mathrm{~b}$ & $0.67 b$ & $0.42 \mathrm{ab}$ & $0.45 \mathrm{ab}$ & $1.05 \mathrm{~b}$ & $1.13 \mathrm{~b}$ & $1.48 \mathrm{~b}$ & $1.46 \mathrm{~b}$ \\
\hline \multirow{4}{*}{$\begin{array}{l}\text { Drought } \\
\text { Stresss } \\
\text { at } 20 \text { days }\end{array}$} & Control Tap water & $0.54 \mathrm{i}$ & $0.61 \mathrm{e}$ & $0.39 \mathrm{~d}$ & $0.44 d$ & $0.93 \mathrm{~g}$ & $1.05 \mathrm{e}$ & $1.37 \mathrm{e}$ & $1.38 \mathrm{e}$ \\
\hline & Silicon 1000 ppm & $0.55 \mathrm{~h}$ & $0.62 \mathrm{de}$ & $0.39 \mathrm{~d}$ & $0.44 \mathrm{~cd}$ & $0.94 \mathrm{fg}$ & $1.06 \mathrm{de}$ & $1.38 \mathrm{e}$ & $1.39 \mathrm{e}$ \\
\hline & Chitosan 150 ppm & $0.56 \mathrm{f}$ & $0.63 \mathrm{~d}$ & $0.39 \mathrm{~cd}$ & $0.44 \mathrm{~cd}$ & $0.96 \mathrm{de}$ & $1.07 \mathrm{~cd}$ & 1.41 cde & $1.41 \mathrm{~cd}$ \\
\hline & Glycine betaine $700 \mathrm{ppm}$ & $0.55 \mathrm{~g}$ & $0.62 \mathrm{~d}$ & $0.39 \mathrm{~d}$ & $0.44 \mathrm{~cd}$ & $0.95 \mathrm{ef}$ & $1.07 \mathrm{de}$ & $1.40 \mathrm{de}$ & $1.39 \mathrm{de}$ \\
\hline
\end{tabular}


Chemical composition of pods

Effect of irrigation intervals

Table 8 show that the highest significant values of vitamin $\mathrm{C}$, carbohydrate, Protein, total sugars contents were at irrigation intervals at 10 days during both seasons compared with irrigation intervals at 20 days which had the lowest significant values of the studied parameters, except TSS which had the highest significant values at 20 days irrigation intervals compared with 10 days irrigation intervals. Similar results are obtained by Farouk and Abd EL Mohsen (2011), Farouk and Ramadan (2012) and Rashed and Moursi (2016).

Chemical composition of okra pod was lower at irrigation intervals at 20 days during both seasons compared with irrigation intervals at 10 days because Water stress is one of the most important limitations to photosynthesis (Tezara et al., 2005).

Water stress reduces total carbohydrates because it's inhibitory effect on photosynthetic pigment concentrations, photosynthetic activities or Rubisco enzyme activity which decreases all sugar fractions (Stibrova et al., 1986).

\section{Effect of foliar application of antitranspirants}

Data shown in Table 8 show that application of chitosan gave the highest values of content of vitamin $\mathrm{C}$, carbohydrate, Protein, total sugars contents of okra pods followed by glycine betaine followed by silicon while control treatment recoded the lowest values. Application of chitosan and glycine betaine had a similar effect on Protein contents in second season. Spraying okra plants with glycine betaine gave the highest values of TSS of okra pods followed by chitosan followed by silicon while control treatment recoded the lowest values of TSS.

These results are agreed with EL-Sherbini (2015) as for silicon, Abdel-Mawgoud et al. (2010) as for chitosan and Aldesuquy et al. (2012) as for glycine betaine.

The positive effect of silicon might be due to silicon enhance the stressful conditions resistance of and improves nutrition supply coordination and supply of micronutrient (Jia et al., 2011)

The positive effect of chitosan on chemical composition of okra pods might be due to greater availability of amino compounds released from it (Chibu and Shibayama, 2001) and increase the uptake and availability of water and essential nutrients (Guan et al., 2009).Chitosan increased photosynthetic rate (Khan et al., 2002) and therefore, increase the accumulation of photosynthesis output compounds in pods.

Concerning glycine betaine, its favorable effect on chemical composition of pods

might be referred to the beneficial effect of it on growth and metabolism and its role as osmoprotectant (Ragab et al. 2015).

\section{Effect of the interactions}

Data in Table 9 show that the highest significant values of vitamin $\mathrm{C}$, carbohydrate, protein and total sugars (\%) contents of okra pods were obtained with the interaction between (irrigation every 10 days $\times$ foliar sprayed by 150 ppm of chitosan) in both seasons followed by (irrigation every 10 days $\times$ foliar sprayed by $700 \mathrm{ppm}$ of glycine betaine) and the lowest one was the interaction between (drought stress irrigation every 20 days $\times$ control) in first and second season.

The highest significant values of TSS contents of okra pods were obtained with (irrigation every 20 days $\times$ foliar sprayed by $700 \mathrm{ppm}$ of glycine betaine) in both seasons followed by (irrigation every 20 days $\times$ foliar sprayed by $150 \mathrm{ppm}$ of chitosan) and the lowest one was the interaction between (irrigation every 10 days $\times$ control). Same results were obtained by Farouk and Abd EL Mohsen (2011), Aldesuquy et al. (2012) and Maghsoudi et al. (2016).

From the obtained results, it could be concluded that Balady cultivar of okra plant sprayed with chitosan at 150 ppm four times, i.e., 20 days after sowing and repeated each 10 days interval, respectively collected the highest total yield /feddan.

Table 8.Effect of irrigation intervals and foliar applications of antitranspirants on Vitamin C, Carbohydrate, Protein, Total sugars (\%) and Total soluble solids (TSS \%) contents of okra pods in the two seasons of 2016 and 2017.

\begin{tabular}{|c|c|c|c|c|c|c|c|c|c|c|c|}
\hline \multirow[t]{2}{*}{ Treatments } & & \multicolumn{2}{|c|}{$\begin{array}{c}\text { Vitamin C } \\
(\mathrm{mg} / 100 \mathrm{~g} \mathbf{w})\end{array}$} & \multicolumn{2}{|c|}{$\begin{array}{c}\text { Carbohydrate } \\
(\%)\end{array}$} & \multicolumn{2}{|c|}{$\begin{array}{c}\text { Protein } \\
(\%)\end{array}$} & \multicolumn{2}{|c|}{$\begin{array}{c}\text { Total sugars } \\
(\%)\end{array}$} & \multicolumn{2}{|c|}{$\begin{array}{l}\text { TSS } \\
(\%)\end{array}$} \\
\hline & & 2016 & 2017 & 2016 & 2017 & 2016 & 2017 & 2016 & 2017 & 2016 & 2017 \\
\hline \multirow{2}{*}{$\begin{array}{l}\text { Irrigation } \\
\text { intervals }\end{array}$} & Normal Irrigation at 10 days & $36.70 \mathrm{a}$ & $40.15 a$ & $27.18 \mathrm{a}$ & $29.21 \mathrm{a}$ & $11.64 \mathrm{a}$ & $12.05 \mathrm{a}$ & $2.80 \mathrm{a}$ & $3.11 \mathrm{a}$ & $10.34 \mathrm{~b}$ & $10.39 b$ \\
\hline & Drought Stresss at 20 days & $32.35 \mathrm{~b}$ & $36.30 \mathrm{~b}$ & $25.41 \mathrm{~b}$ & $28 \mathrm{~b}$ & $10.52 \mathrm{~b}$ & $10.89 b$ & $2.33 \mathrm{~b}$ & $2.59 \mathrm{~b}$ & $11.65 \mathrm{a}$ & $11.69 \mathrm{a}$ \\
\hline \multirow{4}{*}{$\begin{array}{l}\text { Foliar } \\
\text { application }\end{array}$} & Control Tap water & $32.6 \mathrm{~d}$ & $36.7 \mathrm{~d}$ & $25.57 \mathrm{~d}$ & $28.16 \mathrm{~d}$ & $10.75 d$ & $11.09 \mathrm{c}$ & $2.32 \mathrm{~d}$ & $2.58 \mathrm{~d}$ & $10.41 \mathrm{~d}$ & $10.49 \mathrm{~d}$ \\
\hline & Silicon $1000 \mathrm{ppm}$ & $33.86 \mathrm{c}$ & $37.9 \mathrm{c}$ & $26.10 \mathrm{c}$ & $28.44 \mathrm{c}$ & $11.00 \mathrm{c}$ & $11.44 \mathrm{~b}$ & $2.50 \mathrm{c}$ & $2.79 \mathrm{c}$ & $10.77 \mathrm{c}$ & $10.79 \mathrm{c}$ \\
\hline & Chitosan $150 \mathrm{ppm}$ & $36.35 \mathrm{a}$ & $39.82 \mathrm{a}$ & $26.94 \mathrm{a}$ & $29.06 \mathrm{a}$ & $11.33 \mathrm{a}$ & $11.69 \mathrm{a}$ & $2.79 \mathrm{a}$ & $3.11 \mathrm{a}$ & $11.21 \mathrm{~b}$ & $11.23 \mathrm{~b}$ \\
\hline & Glycine betaine $700 \mathrm{ppm}$ & $35.3 \mathrm{~b}$ & $38.48 \mathrm{~b}$ & $26.57 \mathrm{~b}$ & $28.74 \mathrm{~b}$ & $11.24 \mathrm{~b}$ & $11.67 \mathrm{a}$ & $2.66 \mathrm{~b}$ & $2.94 \mathrm{~b}$ & $11.59 \mathrm{a}$ & $11.66 \mathrm{a}$ \\
\hline
\end{tabular}

Table 9. Effect of the interaction between irrigation intervals and foliar applications of antitrranspirants on Vitamin C, Carbohydrate, Protein, Total sugars (\%) and Total soluble solids (TSS \%) contents of okra pods in the two seasons of 2016 and 2017.

\begin{tabular}{|c|c|c|c|c|c|c|c|c|c|c|c|}
\hline \multirow[t]{2}{*}{ Treatments } & & \multicolumn{2}{|c|}{$\begin{array}{c}\text { Vitamin C } \\
(\mathrm{mg} / \operatorname{100gf} \mathbf{w})\end{array}$} & \multicolumn{2}{|c|}{$\begin{array}{c}\text { Carbohydrate } \\
(\%)\end{array}$} & \multicolumn{2}{|c|}{$\begin{array}{c}\text { Protein } \\
(\%)\end{array}$} & \multicolumn{2}{|c|}{$\begin{array}{c}\text { Total sugars } \\
(\%)\end{array}$} & \multicolumn{2}{|c|}{$\begin{array}{l}\text { TSS } \\
(\%)\end{array}$} \\
\hline & & 2016 & 2017 & 2016 & 2017 & 2016 & 2017 & 2016 & 2017 & 2016 & 2017 \\
\hline \multirow{4}{*}{$\begin{array}{l}\text { Normal } \\
\text { Irrigation } \\
\text { at } 10 \text { days }\end{array}$} & Control Tap water & $34.36 \mathrm{~d}$ & $38.66 \mathrm{~d}$ & $26.54 \mathrm{~d}$ & $28.78 \mathrm{~d}$ & $11.25 \mathrm{~d}$ & $11.62 \mathrm{~d}$ & $2.44 d$ & $2.65 \mathrm{~d}$ & $9.73 \mathrm{~g}$ & $9.87 \mathrm{~g}$ \\
\hline & Sili & $36.03 \mathrm{c}$ & $39.8 \mathrm{c}$ & $27.02 \mathrm{c}$ & $29.06 \mathrm{c}$ & $11.45 \mathrm{c}$ & $11.91 \mathrm{c}$ & $2.68 \mathrm{c}$ & $2.96 \mathrm{c}$ & $9.95 \mathrm{f}$ & $9.97 \mathrm{f}$ \\
\hline & n $150 \mathrm{ppm}$ & $38.93 \mathrm{a}$ & $41.64 \mathrm{a}$ & $27.76 \mathrm{a}$ & $29.66 \mathrm{a}$ & $12 \mathrm{a}$ & $12.35 \mathrm{a}$ & $3.17 \mathrm{a}$ & $3.58 \mathrm{a}$ & $10.6 \mathrm{e}$ & $10.61 \mathrm{e}$ \\
\hline & lycine betaine $700 \mathrm{ppm}$ & $37.5 \mathrm{~b}$ & $40.5 \mathrm{~b}$ & $27.42 \mathrm{~b}$ & $29.34 \mathrm{~b}$ & $11.87 \mathrm{~b}$ & $12.33 \mathrm{~b}$ & $2.94 \mathrm{~b}$ & $3.26 \mathrm{~b}$ & $11.1 \mathrm{~d}$ & $11.11 \mathrm{~d}$ \\
\hline \multirow{4}{*}{$\begin{array}{l}\text { Drought } \\
\text { Stresss } \\
\text { at } 20 \text { days }\end{array}$} & Control Tap & $30.83 \mathrm{f}$ & $34.73 \mathrm{~h}$ & $24.61 \mathrm{~h}$ & $27.55 \mathrm{~h}$ & $10.25 \mathrm{~g}$ & $10.56 \mathrm{~h}$ & $2.21 \mathrm{f}$ & $2.51 \mathrm{e}$ & $11.1 \mathrm{~d}$ & $11.11 \mathrm{~d}$ \\
\hline & Silicon $1000 \mathrm{ppm}$ & $31.7 \mathrm{f}$ & $36 \mathrm{~g}$ & $25.19 \mathrm{~g}$ & $27.82 \mathrm{~g}$ & $10.56 f$ & $10.97 \mathrm{~g}$ & $2.33 \mathrm{e}$ & $2.62 \mathrm{~d}$ & $11.6 \mathrm{c}$ & $11.61 \mathrm{c}$ \\
\hline & Chitos & 33.76 de & $38.01 \mathrm{e}$ & $26.13 \mathrm{e}$ & $28.47 \mathrm{e}$ & $10.67 \mathrm{e}$ & $11.03 \mathrm{e}$ & $2.42 \mathrm{~d}$ & $2.63 \mathrm{~d}$ & $11.83 \mathrm{~b}$ & $11.85 \mathrm{~b}$ \\
\hline & Glycine betaine $700 \mathrm{ppm}$ & $3.1 \mathrm{e}$ & $36.47 \mathrm{f}$ & $72 \mathrm{f}$ & $28.15 f$ & $10.62 \mathrm{e}$ & $11.01 \mathrm{f}$ & $2.37 \mathrm{de}$ & $2.63 \mathrm{~d}$ & $12.09 \mathrm{a}$ & $12.21 \mathrm{a}$ \\
\hline
\end{tabular}




\section{REFERENCES}

Abbas,T., Sattar, A., Ijaz, M., Aatif, M., Khalid, S. and Sher, A. (2017). Exogenous silicon application alleviates salt stress in okra. Horticulture, Environment, and Biotechnology 58 (4): 342-349.

Abd El-Kader, A.A., Shaaban, S.M. and Abd El-Fattah, M.S. (2010). Effect of irrigation levels and organic compost on okra plants (Abelmoschus esculentus L) grown in sandy calcareous soil. Agric. Biol. J. North America, 1: 225-231.

Abdel-Mawgoud, A.M.R., Tantawy, A.S., El-Nemr, M.A. and Sassine, Y.N. (2010). Growth and yield responses of strawberry plants to chitosan application. European Journal of Scientific Research, 39(1). 170-177.

Abu-Muriefah, S.S. (2013). Effect of chitosan on common bean (Phaseolus vulgaris L.) plants grown under water stress conditions. Int.Res.J.Agric.Sci.Soil Sci.,3(6): 192-199.

Ahmad, A., Tahir, M., Ullah, E., Naeem, M., Ayub, M., Hasseb-ur-Rehman andTalha, M. (2012). Effect of silicon and boron foliar application on yield andquality of rice. Pak. J. Life Soc. Sci., 10(2): 161165.

Aldesuquy, H. S., Abo- Hamed, S. A., Abbas, M. A. and Elhakem, A. H.(2012). Role of glycine betaine and salicylic acid in improving growth vigour and physiological aspects of droughted wheat cultivars. Journal of Stress Physiology \& Biochemistry, 8 (1): 149-171.

Altaf, R., Hussain, Kh., Ujala, M., Nawaz, Kh., Munir, N. and Siddiqi, E. H. (2015). Effect of different levels of drought on growth, morphology and photosynthetic pigments of lady finger (Abelmoschus esculentus). World Journal of Agricultural Sciences 11 (4): 198-201.

AOAC (1975). official methods of analysis, twelfth Ed. Published by the Association of Official Analytical chemists, Benjamin, France line station, Washington, D.c.

AOAC (2000). Association of Official Analytical Chemists, 17th ED. Of AOAC international published by AOAC international Maryland, U.S.A., $1250 \mathrm{pp}$.

Bukhari, M. A., Ashraf, M. Y., Ahmad, R., Waraich, E. A. and Hameed, M. (2015). Improving drought tolerance potential in wheat (Triticum aestivum 1.) through exogenous silicon supply. Pak. J. Bot., 47(5): 1641-1648.

Chibu, H. and Shibayama, H. (2001). Effects of chitosan applications on the growth of several crops. In: Uragami, T., Kurita, K. and Fukamizo, T. (Eds.), Chitin and chitosan in life science.Yamaguchi, pp: 235-239.

El-Badawy, M.S.A. (2014). Effect of spray with some safety compounds on growth and productivity of some strawberry cultivars. M.Sc.Thesis, Faculty of Agriculture, Benha University, Egypt, 76 pp.
El-Sherbini, M. A. A. (2015). Physiological studies on sugar pea (Pisum sativum L.). ph.D., Thesis, fac. Agric., Mans. univ., Egypt.107pp.

Farouk, S. and Abd EL Mohsen, A. R. (2011). Improving growth and yield of cowpea plant by foliar application of chitosan under water stress. J. Plant Production, Mansoura Univ., 2 (10): 1341 - 1358.

Farouk, S. and Ramadan, A.A. (2012). Improving growth and yield of cowpea by foliar application of chitosan under water stress. Egyptian Journal of Biology, 14:14-26.

Gornik, K., Grzesik, M. and Romanowska-Duda, B. (2008). The effect of chitosan on rooting of grapevine cuttings and on subsequent plant growth under droughtand temperature stress. J.Fruit Ornam.Plant Res., 16: 333-343.

Greger, M., Landberg, T., Vanculik, M. and Lux, A. (2011). Silicon influences nutrient status in plants. Proceedings of the 5th International Conference on Silicon in Agriculture, Beijing, China, pp: 57-58.

Guan, Y., Hu, J., Wang, X. and Shao, C. (2009). Seed priming with chitosan improves maize germination and seedling growth in relation to physiological changesunder low temperature stress. J.Zhejiang Univ. Sci. B, 10(6): 427-433.

Hussein, H. A., Metwally, A. K., Farghaly, K. A., and Bahawirth, M. A. (2011). Effect of irrigation interval (water stress) on vegetative growth and yield in two genotypes of okra. Australian Journal of Basic and Applied Sciences 5(12): 3024-3032.

Jia, J.X., Cai, D.L. and Liu, Z.M. (2011). New progress in silicon-improvement ofquality of crops. Proceedings of the 5th International Conference on Silicon in Agriculture, Beijing, China, pp: 77.

Khan, W.M., Prithiviraj, B. and Smith, D.L. (2002). Effect of foliar application of chitin and chitosan oligosaccharides on photosynthesis of maize and soybean.Photosynthetica, 40(4): 621-624.

Kim, H.J., Chen, F., Wang, X. and Rajapakse, N.C. (2005). Effect of chitosan on the biological properties of sweet basil (Ocimum basilicum L.). Journal of Agricultural and Food Chemistry, 53: 3696-3701.

Koller, H.R. (1972). Leaf area-leaf weight relationships in the soybean canopy. Crop Sci., 12: 180-183.

Korndorfer G.H., Pereira, H.S. and Nolla, A. (2004). Silicon analysis in soil, plant and fertilizers. Brazil, GPSi/ICIAG/UFU.

Lichtenthaler, H. k. and Wellburn, A. R. (1983). Determinations of total carotenoids and chlorophylls $\mathrm{a}$ and $\mathrm{b}$ of leaf extracts in different solvents. Biochem. Soc. Trans., 11(5): 591-592.

Lima Filho, O.F. and Abdalla, A.L. (2008). Production of foliar phenolics and condensed tannins in pigeon pea and leucaena supplemented with silicon. IV Silicon in Agriculture Conference, Wild Coast Sun, KwaZulu-Natal, South Africa, pp:63.

Maghsoudi, K., Emam, Y. and Ashraf, M. (2015). Influence of foliar application of silicon on chlorophyll fluorescence, photosynthetic pigments, and growth in water-stressed wheat cultivars differing in drought tolerance.Turkish Journal of Botany 39: 625-634. 
Maghsoudi, K., Emam, Y. and Pessarakli, M. (2016). Effect of silicon on photosynthetic gas exchange, photosynthetic pigments, cell membrane stability and relative water content of different wheat cultivars under drought stress conditions. Journal of Plant Nutrition 39(7): 1001-1015.

Mahmoud, A. R. and M. M. Hafiz (2002). Effect of irrigation intervals andsulphur application on the growth, yield and nutritive value of eggplant (Solanum melongena var. esculenta L.) Annals of Agricultural Science,Moshotohor, 40(2): 117 11182.

Miri, H. R. and Armin, M. (2013). The interaction effect of drought and exogenous application of glycine betaine on corn (Zea mays L.). European Journal of Experimental Biology, 3(5):197-206.

Mondal, M.M.A., Malek, M.A., Puteh, A.B., Ismail, M.R., Ashrafuzzaman, M. and Naher, L. (2012). Effect of foliar application of chitosan on growth and yield in okra. Australian Journal of Crop Science, 6(5): 918921.

Noreen , S., Zafar, Z. U., Hussain, K., Athar, H.-u.-R. and Ashraf, M. (2015). Assessment of economic benefits of foliarly applied osmoprotectants in alleviating the adverse effects of water stress on growth and yield of cotton (Gossypium hirsutum L.). Pak. J. Bot., 47(6): 2223-2230.

Quan, R., Shang, M., Zhang, H., Zhao, Y. and Zhang, J. (2004). Improved chilling tolerance by transformation with betA gene for the enhancement of glycinebetaine synthesis in maize. Plant Sci. 166, 141-149.

Ragab, M.E., Helal, N. A. S., Sawan, O. M., Fawzy, Z.F. and El-Sawy, S.M. (2015). Foliar application of glycine betaine for alleviating water stress of tomato plants grown under sandy soil conditions. International Journal of ChemTech Research, 8(12): 52-67.
Rakha, M.K.A. (2014). Growth, yield and fruit quality of eggplant (Solanum melongena L.) as affected by irrigation intervals and foliar application of some antitranspirants. J. Plant Production, Mansoura Univ., 5(12): 2069- 2083.

Rashed, N.M. and Moursi, E.A. (2016). Effect of skipping one irrigation during different growth stages and foliar application of micronutrients on roselle (Hibiscus sabdariffa, L.) Plants and some water relations in heavy clay soils. J. Agric. Res. Kafr ElSheikh Univ. 42(1).

Raza, M.A.S., Saleem, M.F., Shah, G.M., Khan, I.H. and Raza, A. (2014). Exogenous application of glycinebetaine and potassium for improving water relations and grain yield of wheat under drought. Journal of Soil Science and Plant Nutrition, 14(2): 348-364.

Sadasivam, S. and Manickam, A. (1996). Biochemical Methods, 2nd Ed. New Age international (P) Limited Publishers, New Delhi P. 42- 43.

Saied, M.M. (2000). Effect of irrigation intervals, furrow irrigation system and nitrogen fertilizer levels on sugar beet yield and its water relations at north delta. J. Agric. Sci. Mansoura Univ., 25 (7): 4737 4745.

Snedecor, G. W. and Cochran, W. G. (1989). Statistical Methods, 8th ed. 2nd Printing. Lowa State Univ. Press, Ame, USA.

Stibrova, M., Doubravova, M., Brezlova, A. and Fridrich, A. (1986). Effects of heavy metals ions on growth and biochemical characteristics of photosynthesis of barley. Photosynthetica 20:416-425.

Tezara, W., Marin, O., Rengifo, E., Martinez, D. and Herrera, A. (2005). Photosynthesis and photoinhibition in two xerophytic shrubs during drought. Photosynthetica, 43(1): 37-45.

\footnotetext{
تأثير الاجهاد المائى وبعض مضادات النتح على نمو وانتاج وجودة نبات الباميا

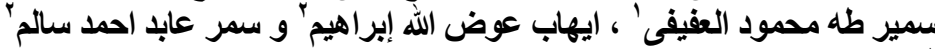

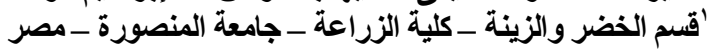

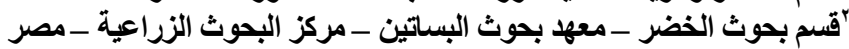

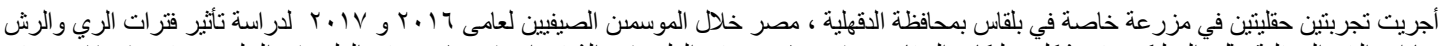

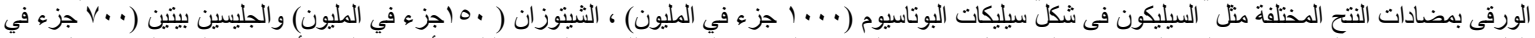

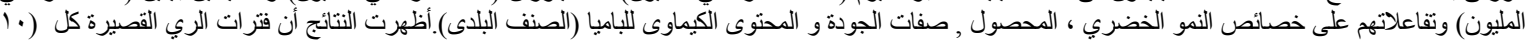

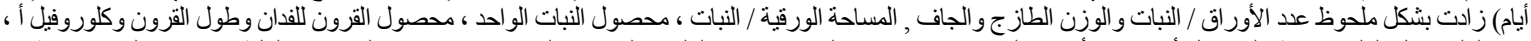

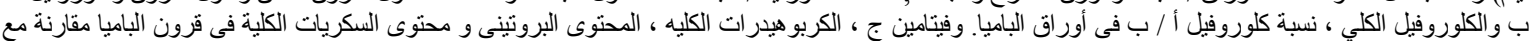

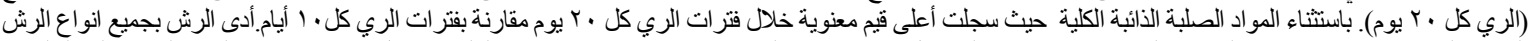

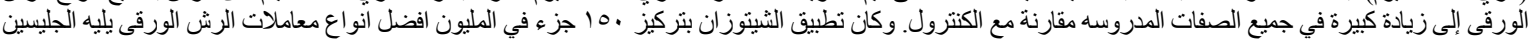

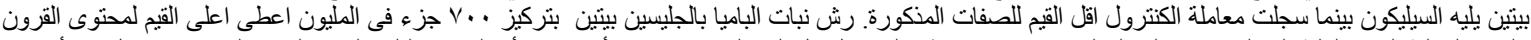

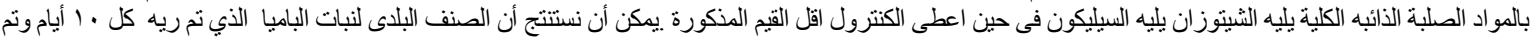

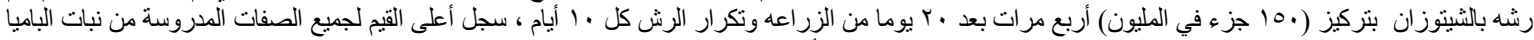

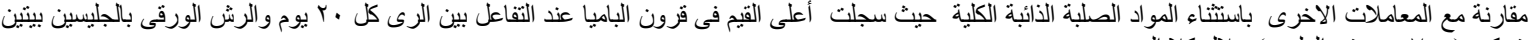

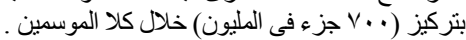

